\title{
Veto, Miklos. 2020. From Budapest to Paris (1936-1957) - An Autobiography. Translated by Rajat D. Acharya. Eugene, Oregon: Resource Publications. 145 pp.
}

\section{Reviewed by Dávid Szőke, University of Szeged beszelo86@gmail.com}

From Budapest to Paris (1936-1957) is a captivating memoir written by Miklos Veto (1936-2020), a Holocaust survivor who was a significant figure of the 1956 Revolution in Hungary and later became an internationally recognized philosopher. Born in Budapest in a Jewish family, he bore witness to the damages of the two totalitarian regimes in Hungary: the fascist and the communist dictatorships. Veto lost his parents as a child during the Holocaust. Adopted by his own uncle and aunt, after the war he continued to study and was admitted to the Faculty of Law at the University of Szeged. During this time, he experienced a spiritual revelation and became a devout Catholic. In mid-1956, as a student of law at the University of Szeged, he was one of the founders of the MEFESZ - Magyar Egyetemisták és Föiskolai Egyesületek Szövetsége ['Hungarian Federation of University and College Students' Associations'], which played a key role in preparing and launching the 1956 Revolution. To escape punishment for his participation in the revolution, later Veto had to leave Hungary and settled in France, where he earned a Master's degree in philosophy at Sorbonne University (1957-1959). He then wrote his Ph.D. about the religious metaphysics in the work of Simone Weil at the University of Oxford, under the supervision of Iris Murdoch (1959-1963). With a career spanning six decades, he taught at Marquette (1963) and Yale Universities (1965-1975) in the United States, the University of Abidjan in the Ivory Coast (1975-1979), and the Universities of Rennes (1979-1992) and Poitiers (1992-2005) in France. Throughout his career, Veto published about German Idealism, religious philosophy, and metaphysics in English, French, and Hungarian.

In his autobiography Veto focuses on his early years in Hungary devoting only a postface about his sixty years in emigration. In three chapters, Veto powerfully evokes the sociopolitical environment of interwar Hungary, the deportations of Jewish people from Budapest, the Szálasi terror, the changing political atmosphere in Hungary after the war, and the national uprising in 1956. However, Veto's narrative is much more than just a mere recollection of events, as each page is filled with the author's devotion to the Catholic faith, his loving memory of his lost family, and his deep attachment to Hungary. Thus, the book can be read in at least two ways or on two levels. On one level it can be seen as the author's effort to give meaning to the past, the darkness of the Holocaust, the brutality of the Soviet regime, and his own forced emigration from Hungary. On another level, the work can be approached as a spiritual and religious selfreflection on the author's journey toward his discovery of the Catholic faith and his way of looking back on his past in full assurance of his religious belief.

(cc) BY

ULIS D-Serle
New articles in this journal are licensed under a Creative Commons Attribution 4.0 International License.

This journal is published by the University Library System of the University of Pittsburgh as part of its D-Scribe Digital Publishing Program and is cosponsored by the University of Pittsburgh Press 
Szőke, Dávid. "Veto, Miklos. 2020. From Budapest to Paris (1936-1957) - An Autobiography. Translated by Rajat D. Acharya. Eugene, Oregon: Resource Publications. 145 pp." Hungarian Cultural Studies. e-Journal of the American Hungarian Educators Association, Volume 14 (2021) DOI: 10.5195/ahea.2021.454

In Chapter One, Veto recalls his early childhood and the family's feudal life in Felcsút, a small Northern-Hungarian town, which they had to leave for Budapest in 1943, after a legal decree was announced on September 6, 1942, by which the agricultural property of the Jews had to be handed over to non-Jews. Veto describes his family with great affection, especially his grandmother who, as he writes, was not a practicing Jew, yet "was the only member of the family who looked positively upon being Jewish" (8). By contrast, Veto's grandfather, the vicepresident of the liberal party in Hungary, "Hungarianized his name from Weisz to Veto [because] he barely had any attraction for his religion from birth" (8). Veto's father, a "passionate patriot" (7), who, at eighteen, had enlisted in the White Army of Miklós Horthy, was a proud landowner; but then, driven by mental depression, in 1941 he committed suicide. Three days after the death of his father, worrying about the future of his two sons, Veto's extended family members had him and his brother baptized at a church in Budapest. His mother took over the direction of their property until in 1943 they were forced to leave. Veto argues that although his uncle, a Christian lawyer, managed to convince the Supreme Court to return his grandmother's house to the family, the juridical decision was never followed. As Veto notes, this turned out to be fortunate since the remaining Jewish population of the area was deported and murdered in Auschwitz in April 1944.

In Chapter Two, Veto depicts his childhood and adolescence in Budapest. He was living with his maternal grandmother in Budapest when, at the request of his mother, Veto was unofficially adopted by his aunt and uncle. In July 1944, while visiting his brother in a hospital in Budapest, Veto's mother was arrested and deported to Auschwitz, then to a German camp near Frankfurt, where she was assigned to a forced-labor unit deployed in the construction of a large airport. Afterward, she was transferred to Ravensbrück and eventually perished in Salzwedel, a satellite camp of Ravensbrück, two days after liberation. Meanwhile, in Budapest, as the Arrow Cross Party rose to power, many Jewish people were rounded up and killed by gunfire at the banks of the Danube. Among the survivors of these raids were Veto's two aunts who, understanding what was going to happen, began to run, and although they were shot at, the bullets missed them. During this period Veto was put in a convent by his adoptive parents. He writes that life in the convent was "severely strict, we ate poorly, and it was necessary to attend Mass at six o'clock each morning” (17). However, he and his brother survived in the convent until shortly before liberation.

Despite the rising political tensions in the countries of the entire East-Central Europe, Veto describes the years between 1945 and 1949 as mostly peaceful. Budapest was revived from the ruins of the war, and the cultural life of the city was restored. Veto's adoptive father had survived the horrors of Bergen-Belsen concentration camp, where he was deported in November 1944, and returned to his family. Between 1945 and 1946, Veto prepared for his First Holy Communion, an event he says left almost no traces in his memory because, as he recounts: "I considered myself an atheist, and I said as much to everyone" (27). During this time, he enrolled in the French section of the Madách Imre Secondary School, where he was at odds with many of his teachers but did appreciate the literary education he received, enthusiastically reading Shakespeare, Lermontov, and Baudelaire; and he also studied French until it was abolished from the curriculum and replaced by the Russian language. 
Szőke, Dávid. "Veto, Miklos. 2020. From Budapest to Paris (1936-1957) - An Autobiography. Translated by Rajat D. Acharya. Eugene, Oregon: Resource Publications. 145 pp." Hungarian Cultural Studies. e-Journal of the American Hungarian Educators Association, Volume 14 (2021) DOI: 10.5195/ahea.2021.454

Veto's religious conversion, his participation in the 1956 Revolution, and his escape to France are all depicted in Chapter Three. Through his adoptive mother's intervention, in 1954 he was admitted to the Faculty of Law at the University of Szeged. Veto is very critical of this Faculty, describing it as "a garbage dump" (41), where a number of professors, generally workers or peasants selected for their political loyalty, "were assisted by students just a little older than us" (41). In the autumn of 1954, during Mass, Veto experienced "a levitation: I had been elevated a few centimeters [...] above the ground" (38), and this spiritual encounter turned him into a faithful Catholic. From then on, Veto writes, the spiritual awakening he went through governed his life, and the Catholic faith became for him "the force which makes me be and act, which inspires and articulates my thought, which constitutes the strongest identity of my life" (73).

The turmoil of the 1956 Revolution greatly affected Veto's thought about the evils of totalitarianism. On October 23, while protest demonstrations were taking place on the streets of Budapest and Szeged, Veto, along with two other students, was elected to be a leader of MEFESZ. On November 1, the Hungarian Government denounced the Warsaw Pact and declared the neutrality of Hungary, which Veto received with great joy. However, on November 4 the people's hope that communism would once and for all be abolished was shattered with the arrival of the first Soviet troops in the Hungarian capital. Yet, the students' revolutionary organization was still operating. On November 15 Veto received a book containing a list of agents working in the countryside for the ÁVH, the Hungarian Secret Police. His task was to make a summary of the personal data of agents working in the churches and comments about their case officers. As Veto explains, the very existence of the book proved to be disastrous for its holders. Soon, some members of the students' network working on the same or similar lists either turned out to be traitors or were betrayed by others, and eventually all of them were arrested. During this time, Veto wrote an open letter to Prime Minister János Kádár, in which he held Kádár's government accountable for prohibiting free elections, for crushing the revolution with the help of the Soviet military forces, for not allowing United Nations observers into Hungary, and for imprisoning Hungarian people. With the help of a friend and another member of MEFESZ, Veto managed to flee to France via Yugoslavia along with six hundred other Hungarian refugees.

The book's postface deals with Veto's academic career, his marriage, his settling in France, where he became a naturalized citizen in 1970, and it offers some meditations on the author's lifelong national and religious identity. Despite the traumas of the Holocaust and the Soviet occupation of Hungary, Veto continued to feel a strong attachment to his country of birth. As for his Jewish identity, he tries to comprehend it through the Catholic faith, which he calls a force uniting both his Hungarian and his Jewish identity. As he argues, it is his Catholic faith and identity through which he tries to understand and come to terms with his past. The book is illustrated with professional letters from philosophers and writers such as Gershon Scholem, Paul Ricoeur, Iris Murdoch, and Gabriel Marcel, as well as with the original transcript of Veto's open letter to Kádár, the cover page of the Hungarian Secret Police dossier, a 1968 article of the Yale Daily News on Veto's recollections of the 1956 Revolution, and some photos from the author's life, all of which testify to his accomplishments. 
Szőke, Dávid. "Veto, Miklos. 2020. From Budapest to Paris (1936-1957) - An Autobiography. Translated by Rajat D. Acharya. Eugene, Oregon: Resource Publications. 145 pp." Hungarian Cultural Studies. e-Journal of the American Hungarian Educators Association, Volume 14 (2021) DOI: 10.5195/ahea.2021.454

With its precise depiction of the postwar social and political circumstances in Hungary, Miklos Veto's memoir provides an exceptional insight to the lives of ordinary people in those turbulent years. At the same time, Veto's account on his life is a delightful and thoughtprovoking self-reflection that reveals the doubts, worries, and hopes of a young revolutionary, and the intellectual and spiritual journey of the philosopher and the faithful Catholic he has become. All this is written with a loving devotion to Veto's family, his fellow students and revolutionaries, and to God, who made the author's personal and professional achievements possible. 